\title{
REVITALISATION OF ORLÍK RESERVOIR - CASE STUDY OF A REGIONAL RESTORATION PROJECT
}

\author{
IVANA OČÁSKOVÁ ${ }^{1}$, JAROSLAV VRBA ${ }^{2,3, *}$, and LUBOŠ PRŮŠA ${ }^{4}$ \\ ${ }^{1}$ Association of Písek District's Municipalities, Velké náměstí 114/3, 39701 Písek \\ 2 Faculty of Science, University of South Bohemia, Branišovská 31, 37005 České Budějovice, Czech Republic \\ ${ }^{3}$ Biology Centre AS CR, Institute of Hydrobiology, Na Sádkách 7, 37005 České Budějovice, Czech Republic \\ ${ }^{4}$ South Bohemian Regional Assembly, U Zimního stadionu 1952/2, 37076 České Budějovice \\ * Corresponding author: jaroslav.vrba@prf.jcu.cz
}

\section{ABSTRACT}

\begin{abstract}
This case study describes the bottom-up formation of a regional project for restoring a reservoir. Land use changes in the upper Vltava river basin caused the eutrophication of Orlík reservoir, which resulted in water blooms, which in association with socio-economic changes caused a decline in tourism in this region and serious difficulties for local people. The study examines how public awareness helped in the establishment of a restoration project, its framework and strategy. Regional governance of the project management took into consideration both knowledge-based solutions and the interests of local people and municipalities. The project has the potential for resolving both environmental and socio-economic problems and providing a sustainable win-win strategy for the region, residents, tourists and stakeholders.
\end{abstract}

Keywords: Vltava river basin, eutrophication, socio-economic transformation, regional governance, science-based sustainable strategy

\section{Introduction}

Cultural eutrophication is the primary water quality issue for most lowland freshwater and coastal marine ecosystems in the world (Smith and Schindler 2009). Phosphorus is recognised as an important driver of biological activity in freshwater and its supply needs to be managed in order to avoid eutrophication associated with urbanisation and agricultural intensification (Withers and Jarvie 2008). According to a comprehensive review of cultural eutrophication (Schindler 2012), the only method that has proved successful in reducing the eutrophication of lakes is to reduce phosphorus input. There is no evidence to support recent claims that to reduce eutrophication it is also necessary to simultaneously control nitrogen input. Before implementing expensive policies to reduce nitrogen input its effectiveness at the ecosystem-scale needs to be verified (Schindler 2012).

The EU Water Framework Directive (WFD 2000) initiated a shift towards a targeted approach to implementation by focusing on river basins in Europe as management units and the natural ecological characteristics of water bodies where the effects of phosphorus has received considerable attention. For instance, the programme of River Basin Management Plans adopted has targeted measures that are likely to mitigate the effect sources of diffuse phosphorus in Irish catchments (Doody et al. 2012). In the Czech Republic, Hejzlar et al. (2010) recently studied the balance in the source of phosphorus and nitrogen in the upper Vltava river basin. This catchment area is typical of the developments that occurred in central and eastern European countries with the socio-economic shift from a market to a planned economy in the 1950s and back to a market economy in the 1990s (Kopáček et al. 2013a, 2014). Factors controlling the nitrogen export from agricultural land in this large heterogeneous catchment have been documented since 1959 (Kopáček et al. 2013b). All the changes in land use affected not only water quality (i.e. eutrophication, water blooms, etc.) but also regional socio-economic circumstances.

Orlík reservoir is the largest body of water by volume in the Czech Republic and a step in the cascade of manmade impoundments on the Vltava river (Straškraba et al. 1973). Its dam was built in a deep valley in a middle stretch of the river approximately 90 kilometres upstream from Prague in the early 1960s. The impoundment extends $68 \mathrm{~km}$ along the Vltava river and an additional $22 \mathrm{~km}$ or $7 \mathrm{~km}$ upstream in its lateral tributaries, the rivers Otava and Lužnice, respectively (Fig. 1). The total area of the Orlík reservoir covers 2,733 ha and maximum volume is 716.5 million $\mathrm{m}^{3}$. Besides its main purposes, storage of water for producing hydroelectricity, improving the flow of the river downstream and partial flood protection, this man-made lake soon became famous for recreation, water sports and angling. After two decades, however, the prosperous business associated with tourism gradually declined due to the occurrence of massive water blooms in Orlík reservoir, which resulted over the next two decades in an almost complete collapse of tourism in this region (Průša 2009a).

This case study focuses on both the environmental drivers and socio-economic pressures of the last half-century that resulted in the "ageing of the reservoir". We analyze how the building of Orlík reservoir changed the surrounding region, eutrophication and socio-economic transformation caused a decline in tourism in this region and public awareness helped to resolve the regional problems and develop plans for sustainable tourism. 


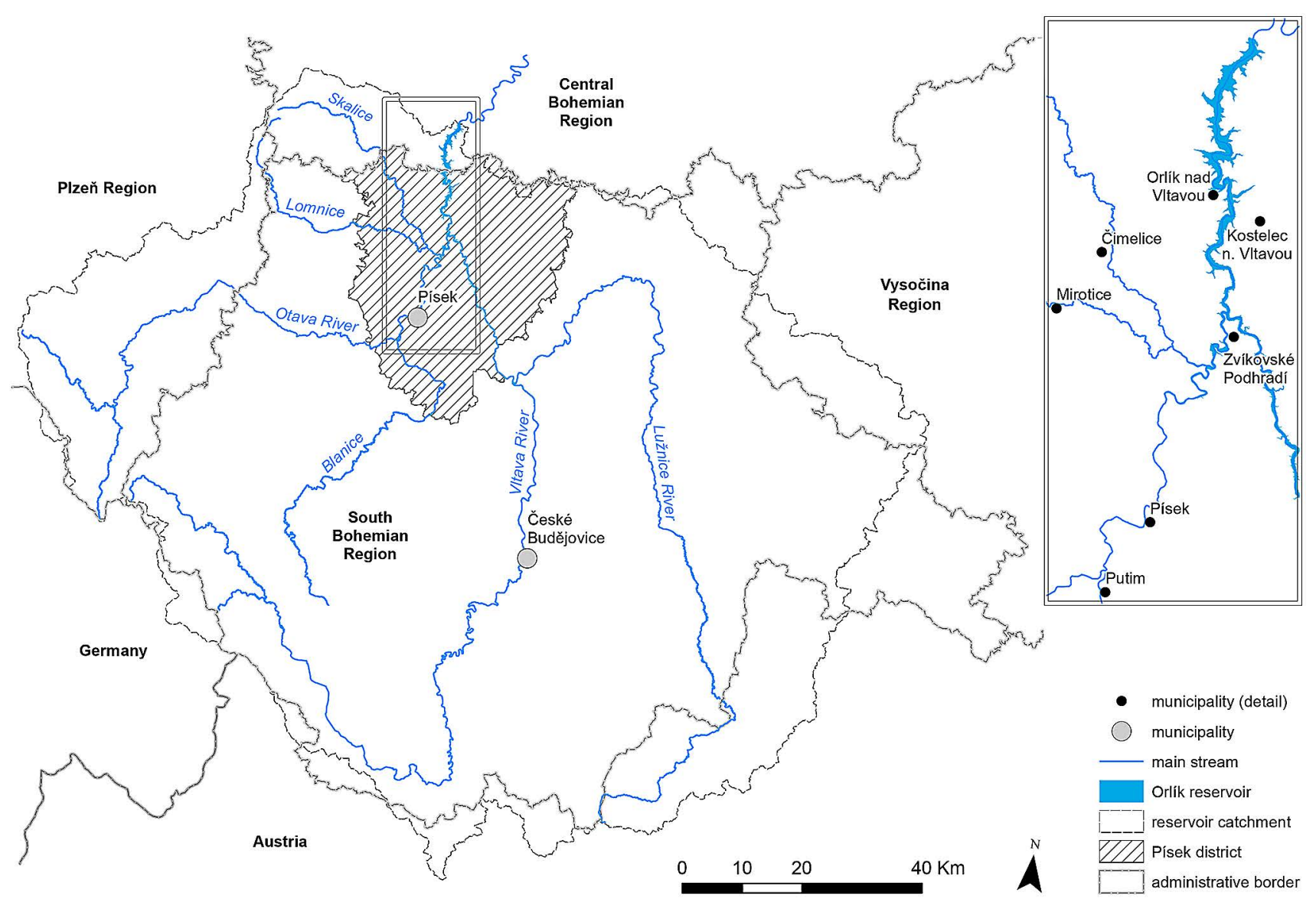

Fig. 1 Orlík reservoir - a schematic map of the entire catchment area with major tributaries, overlaid with a map of the South Bohemian Region (hatched area indicates the location of the Association of Písek District's Municipalities) and adjacent regions and/or countries; the surroundings of the reservoir are presented in more detail with some of the sources of municipal pollution indicated (see text for status of their wastewater treatment plants).

\section{Historical Background}

Construction of the $91 \mathrm{~m}$ high dam began in April 1957 and the filling of the reservoir with water started in 1960. Long stretches of the Vltava river, as well as both the rivers Otava and Lužnice, with their characteristic canyon-like valleys were flooded with a vast amount of water in 1966. This huge body of water fundamentally changed the character of the surrounding landscape and life of the riverine population. Weirs and rapids disappeared. The rivers became silent. The lives of many people completely changed. Some residents had to leave their homes as they were flooded in the river valleys. Others were forced to change their employment due to loss of traditional jobs, e.g. in the inns and hotels situated on the banks of the rivers. Building the cascade of reservoirs also brought to an end the several hundred-year-old tradition of transporting timber in the form of rafts down the river Vltava and canoeing, which became popular during the 20th century. The many river ferries and fords disappeared and parts of historical trails and roads were flooded and replaced by only a few bridges. Hence, people living on both sides of the new lake were more isolated from one another than in the past. On the other hand, the con- struction of Orlík reservoir brought many positive opportunities to the region. New holiday resorts, hotels and camping places were built on the shores of the lake. The area became popular for summer holidays, water sports, yachting and angling. Orlík reservoir was indeed one of the most popular tourist destinations in Czechoslovakia in the 1970s and early 1980s. During this period, hundreds of thousands of domestic holidaymakers visited the region every summer, partly due to the very restricted opportunity to travel abroad, e.g. to the sea side. Thus the region generated many new job opportunities that were, however, largely limited to the summer holiday season.

Unfortunately, overall quality of the water in Orlík reservoir gradually deteriorated during the 1980s and water blooms occasionally occurred in the transition zones of both the Vltava and Otava inflows. Since then, the situation has worsened with regular occurrences in space and time of water blooms depending on weather conditions and an increase in the eutrophication of Orlík reservoir. As a consequence, the number of visitors has declined from year to year. This trend even accelerated after 1990 when people were allowed to travel and holiday abroad and far fewer visitors came from the former German Democratic Republic. 
In response to this sudden drop in the number of tourists and changes in the overall socio-economic conditions, most of the holiday resorts in this region previously owned by state enterprises or trade unions underwent rather undirected privatization, which unfortunately was not very successful (Průša 2009a). Due to lack of local capital, both privatization and maintenance of tourist infrastructure was mainly funded and organized from outside the region; hence, any profit left the region. This also affected the quality of the services available for visitors because most of the lessees were little motivated to provide a high quality of service for their guests, who responded by going elsewhere. This positive feedback resulted in a reduction in income, old-fashioned tourist infrastructure, bankruptcies and an increase in unemployment in this region. Local residents had to look for work outside the region or even move elsewhere. Thus the number of inhabitants in many villages around the Orlík reservoir has decreased and the proportion made up of old people has increased.

\section{Public Awareness and Project Design}

Worsening of natural conditions, i.e. water quality and phytoplankton blooms in Orlík reservoir, and the overall deterioration in the services and infrastructure for tourists caused serious complications. Socio-economic problems similarly affected the whole region around Orlík reservoir, which is located across the boundary of two autonomous regions, but the severity of environmental problems decreased along a longitudinal gradient in surface water quality from the polluted tributaries to the reservoir. Water blooms occurred more often and extensively in the tributaries and usually lasted for longer than in the middle part of Orlík reservoir and especially in the lacustrine parts near the dam (Liška et al. 2009; Duras et al. 2011). Therefore, the concern about poor water quality was greater in the South Bohemian Region than the Central Bohemian Region. The latter is responsible for only about a quarter of the shoreline of the reservoir (see Fig. 1). This is why the Association of Písek District's Municipalities includes representatives of 72 local municipalities in the South Bohemian Region, and functions by discussing their problems with scientists and regional politicians. The several meetings held since the mid-2000s have resulted in a knowledge-based governance process for resolving the region's problems.

Limnologists predicted the eutrophication of Orlík reservoir a long time ago (e.g. Procházková 1977; Straškrabová et al. 1994). Its catchment area of $12,116 \mathrm{~km}^{2}$ includes almost the entire South Bohemian Region, part of the Plzen Region, Central Bohemian Region and Vysočina Region (Fig. 1). The total population in the catchment area exceeds 700 thousand people, almost $80 \%$ of which are connected to the communal drinking water supply and sewerage systems (Hejzlar et al. 2010).
The experts are well aware that progress in sanitation can, in particular, result in an enhanced phosphorus loading of sewage and, if not effectively removed, increase in pollution. In addition to the overall growth in living standards (public water supply, sewerage, WC, washing machines, dishwashers, phosphate-rich detergents, etc.) over the past fifty years, intensification of both agriculture (use of fertilisers, livestock sewage, soil amelioration, erosion, etc.) and fisheries (feeding, fertilization, etc.) within its large catchment area have greatly increased the potential for the eutrophication of Orlík reservoir and stream channelization has impaired self-purification and the retention of nutrients in many of the tributaries of the reservoir. It was just a matter of time and occurrence of favourable weather conditions before massive water blooms occurred. Though the experts repeatedly tried to draw attention to this danger, their warnings were ignored by both the public and decision makers.

Unfortunately, the experts' predictions gradually became a reality, with ugly green carpets covering some parts of the reservoir surface every summer starting more than two decades ago. This discouraged tourists from visiting the region and resulted in a reduction in job opportunities. Holiday resorts emptied and fell into disrepair. The area surrounding Orlík reservoir became the inner periphery, i.e. a neglected region with minimum investment, decaying infrastructure and a high unemployment rate (Musil and Müller 2008).

In 2007, local representatives of the Association of Písek District's Municipalities initiated regional discussions and fruitful cooperation between experts from the Vltava River Authority, research institutions and universities, representatives of regional stakeholders and the South Bohemian Regional Authority. This consortium organized the first conference on the Revitalisation of Orlík reservoir, held in the city of Písek in 2008, which reviewed the major regional problems and suggested a framework for knowledge-based solutions and sustainable development of the region. A regional framework for the Revitalisation of Orlík reservoir evolved in a bottom-up process under the governance of the Association of Písek District's Municipalities. In 2009, the Association established a scientific board that has since coordinated and managed all the projects. In addition to the Association of Písek District's Municipalities, current members of the Scientific Board represent the Institute of Hydrobiology of the Biology Centre ASCR, the Research Institute for Soil and Water Conservation, the University of South Bohemia in České Budějovice, the Vltava River Authority, the Fishery Corporation CR and the South Bohemian Regional Authority. Regional governance had only a subsidiary role in managing the projects the major target groups of which are local people and municipalities, or regional stakeholders, who are exposed to all of the above mentioned problems. 


\section{Project Strategy}

From the very beginning of the project the high concentrations of nutrients, particularly phosphorus, in the tributaries were considered to be the main cause of water blooms in Orlík reservoir, whereas internal phosphorus loading from the bottom sediments in this deep and stratified reservoir was not seen as an important source of eutrophication. In addition, if there is a sufficient inflow of nitrate to prevent hypolimnetic anoxia (cf. Liška et al. 2009) the bottom sediments are not an important source of phosphorus and their removal need not be considered. The first conference identified the major sources of eutrophication and miscellaneous sources of either point or diffuse pollution in the catchment area of the reservoir. The Scientific Board then addressed the following questions: how much and from where? The experts agreed on a thorough revision of all existing data on water quality within the entire catchment area of the reservoir and proposed a general strategy for the revitalisation of Orlík reservoir that was presented at the second conference in 2009 (Průša 2009b).

The Strategy included the following steps: (i) identify and quantify nutrient pollution sources in the catchment area and suggest alternative ways of reducing the nutrient loading of the reservoir; (ii) suggest measures, complete with individual cost-benefit analyses, for reducing the input of phosphorus from the major sources in the catchment area; (iii) select based on the above and prepare particular projects for implementation; and (iv) apply selected measures. It was clear that the recovery of tourism and regional development could only be achieved by improving water quality. The Strategy provided a procedure for improving, within $10-15$ years, the quality of the water in Orlík reservoir to a level suitable for swimming in during summer. In addition, the Strategy was an efficient way implementing the EU Water Framework Directive (WFD 2000) in the entire catchment area (e.g. River Basin Management Plans, cf. Doody et al. 2012).

\section{Balance Study}

First, the Institute of Hydrobiology carried out a Balance Study, i.e. the balance in the sources of phosphorus and nitrogen within the Orlík reservoir catchment (Hejzlar et al. 2010) funded by the Vltava River Authority. Hejzlar et al. (2010) used current technology and adapted models to take into account the conditions in Orlík reservoir and its catchment area. They used all the available data, including geographic information and expert estimates of the balance of phosphorus and nitrogen in particular sub-catchments. This study is quite unique and is possibly the most detailed nutrient balance ever calculated for a large river basin. There is no similar study for any other river system in the Czech Republic.

The results of this study are not surprising and confirm that eutrophication of Orlík reservoir is exclusively caused by the high phosphorus input from the catchment area and that the influence of nitrogen is negligible. The annual phosphorus loading is three times greater than the retention capacity of Orlík reservoir. In other words, if the current phosphorus loading of the reservoir is reduced by about two thirds for long time this would result in the required level of water quality. The study identified the majority of the nutrient sources in the different sub-catchments, quantified their size and assessed their importance (Hejzlar et al. 2010).

Three types of phosphorus sources were identified: (i) municipal sewerage systems, either releasing untreated sewage, or wastewater treatment plants operating without efficient phosphorus removal; (ii) fishponds in some sub-catchments, which released phosphorus under certain circumstances (e.g. anoxia, over feeding, or over fertilizing); and (iii) several local sources for which there is a lack of data and some localities with either improper livestock sewage treatment, or agricultural releases (over fertilization, erosion, etc.). The excessive release of phosphorus may be associated with specific malpractices, e.g. in wastewater treatment, aquaculture and fishpond management, livestock and crop production. Indeed corrective measures based on compliance with good practice would currently be the cheapest solution. On the other hand, some sources, such as fishpond ecosystems, require a better understanding of their current hypertrophic status. While most fishponds should in theory retain phosphorus, neither the Balance Study (Hejzlar et al. 2010) or current fishpond monitoring (Potužák et al. 2010a,b, 2011) have confirmed this assumption. It could indicate that aquaculture is too intensive, with insufficient primary production or weak transformation along the food chain, high internal phosphorus loading and an enhancement of the phosphorus loading from an inflow.

In addition, this study considered several scenarios for reducing phosphorus input. The consequent Feasibility Study should analyze the technological, legal, or socio-economic feasibility of the particular scenarios, carry out cost-benefit analyses and suggest measures for reducing the sources of phosphorus.

\section{Current Progress}

This study revealed that phosphorus pollution is not similar throughout the entire catchment area. For instance, the basins of the Lomnice stream and river Lužnice are the most phosphorus polluted sub-catchments. While small direct tributaries of Orlík reservoir contribute negligible quantities of phosphorus it is sufficient to cause local water blooms in adjacent bays. Therefore, not only is the overall Strategy, i.e. current preparation of the Feasibility Study and its funding, being implemented but also the correction of identified malpractices, if applicable, and local measures for improving any single pollution source. Whereas this needs efficient cooperation on a large scale and effective coordination by the South Bohemian Region Authority and/ 
or the Vltava River Authority, the other measures require subsidiarity based on local solutions and participative management.

Thus, in addition to focusing on the entire catchment area and its synergy in reducing overall phosphorus loading of the reservoir, the Association of Písek District's Municipalities pays particular attention to the area closest to Orlík reservoir. The municipalities there have built sewerage and wastewater treatment plants the majority of which do not have proper technology, if any, for removing phosphorus. Even relatively large municipalities, such as Mirotice and Čimelice, each with more than one thousand inhabitants, still lack a central wastewater treatment plant. So that wastewater, partly pre-treated in septic tanks, flows directly into the highly polluted Lomnice stream sub-catchment area (see Fig. 1).

Hence, the Association assists its members in establishing treatment plants for sewerage and wastewater, in particular those settlements surrounding Orlík reservoir. Three projects have been successfully completed and wastewater treatment plants with facilities for enhanced phosphorus removal are already operational at Zvíkovské Podhradí, Putim and Kostelec nad Vltavou. Building of two wastewater treatment plants at Čimelice and Orlík nad Vltavou is currently in progress (Fig. 1). Four other projects have recently been approved for funding in the near future. All these projects include facilities for enhanced phosphorus removal. Even if all the villages surrounding Orlík reservoir build treatment plants for sewerage and wastewater, however, it would not guarantee clear water in the lake, but is likely to result in an improvement in the quality of the water in adjacent bays.

In parallel, some preliminary work has begun, but it has not always been easy to precisely specify the tasks for potential contractors and avoid pitfalls that hinder negotiations. Moreover, the recent economic depression and political turbulence have complicated and delayed successful completion of the Feasibility Study.

Despite serious environmental problems, however, local people look forward to improved socio-economic conditions and sustainable life. The main targets of the project to revitalise Orlík reservoir are sustainable tourism and regional development. Although the current conditions for tourism are bad (e.g. Průša 2009a) and businessmen have to contend with uncertain economic and/or unfavourable weather conditions, which have resulted bankruptcies and even suicides, there is a great potential for improving the situation. The Association of Písek District's Municipalities has initiated mutual co-operation among businessmen to attract visitors back to the region, which needs them to act together in representing one tourist destination. The Association initiated several activities to advertise the region over the last three years, such as seminars informing businessmen about available grants and other opportunities, regional broadcasting, posters or flyers advertising summer cultural events, music festivals, etc. This was appreciated and further developed and improved as a crucial tool for promoting regional tourism. Last but not least, Orlík reservoir is much more than just a lake, e.g. it is a beautiful landscape with a rich nature, hundreds of kilometres of cycle tracks, many castles and other historical buildings.

\section{Conclusions}

This case study presents a unique and up to now successful project for the revitalisation of Orlík reservoir, which not only targets the restoration of the reservoir as essential for sustainable tourism and development of the region surrounding the reservoir but is also necessary for implementing the EU Water Framework Directive in the upper Vltava river basin, i.e. in the whole South Bohemian Region and even beyond. It is the largest and most complex attempt to improve water quality on a catchment scale in this country. The whole framework was developed using a bottom-up process reflecting mutual trust of all parties, i.e. local and regional municipalities, multidisciplinary experts, and both key regional and local stakeholders.

We believe it is a good example of "science based" governance of sustainable life based on subsidiarity. The Association of Písek District's Municipalities helped prepare the communal projects for treating sewage and efficiently removing phosphorus, which is one-order-of-magnitude cheaper than building expensive nitrogen removal technology. The tradition of holding an annual conference in Písek has greatly improved overall public awareness of both environmental and socio-economic problems and pitfalls of adopting "miraculous" technologies or products. Moreover, the Association coordinates joint activities of the emerging tourism business. The project's Scientific Board proposes knowledge-based solutions and implements the proposals of both the Balance and Feasibility Studies. The South Bohemian Regional Authority, in cooperation with other neighbouring regional authorities and the Vltava river Authority guarantee the political and legal framework for applying the best and most efficient measures within the catchment area. Last but not least, the success of the project for revitalising Orlík reservoir needs the support of the Czech government, in particular the Ministry of Environment, Ministry of Agriculture and Ministry of Local Development and further funding from whatever source including the EU Cohesion Policy.

The revitalisation of Orlík reservoir will provide a great potential and synergy for resolving the socio-economic and environmental problems, and is a good example of a sustainable win-win strategy for the region, local people, tourists, stakeholders, as well as water and agricultural policies. 


\section{Acknowledgements}

This study was funded by project OP VK CZ.1.07 12.4.00/17.0130. Stanislav Grill kindly provided the map.

\section{REFERENCES}

Doody DG, Archbold M, Foy RN, Flynn R (2012) Approaches to the implementation of the Water Framework Directive: Targeting mitigation measures at critical source areas of diffuse phosphorus in Irish catchments. J Environ Manage 93: 225-234.

Duras J, Liška M, Potužák J (2011) The Orlík reservoir in 2011. In: Borovec J, Očásková I (eds) Revitalizace orlické nádrže 2011. Svazek obcí regionu Písecko, Povodí Vltavy, státní podnik a Biologické centrum AVČR, pp. 25-33. (in Czech)

Hejzlar J, Borovec J, Mošnerová P et al. (2010) The balance of phosphorus and nitrogen sources in the Orlík reservoir catchment. Unpubl. report for the Vltava River Authority, Biology Centre ASCR, České Budějovice (in Czech)

Kopáček J, Hejzlar J, Posch M (2013a) Quantifying nitrogen leaching from diffuse agricultural and forest sources in a large heterogeneous catchment. Biogeochemistry 115: 149-165.

Kopáček J, Hejzlar J, Posch M (2013b) Factors controlling the export of nitrogen from agricultural land in a large central European catchment during 1900-2010. Environ Sci Technol 47: 6400-6407.

Kopáček J, Hejzlar J, Porcal P, Posch M (2014) Sulphate leaching from diffuse agricultural and forest sources in a large central European catchment during 1900-2010. Sci Total Environ 470-471: 543-550.

Liška M, Duras J, Potužák J (2009) Water quality development in the Orlík reservoir. In: Revitalizace orlické nádrže 2009. Vysoká škola technická a ekonomická v Českých Budějovicích, pp. 12-30. (in Czech with English summary)

Musil J, Müller J (2008) Inner peripheries of the Czech Republic as a mechanism of social exclusion. Sociologický časopis/Czech Sociological Review 44: 321-348. (in Czech with English summary)

Potužák J, Duras J, Borovec J et al. (2010a) První výsledky živinové bilance rybníku Rožmberk s posouzením vlivu na řeku Lužnici. In: Borovec J, Očásková I (eds) Revitalizace orlické nádrže
2010. Svazek obcí regionu Písecko a Biologické centrum AVČR, pp. 99-117.

Potužák J, Duras J, Borovec J, Rucki J (2010b) Rybníky Dehtář a Hejtman - látkové bilance. In: Borovec J, Očásková I (eds) Revitalizace orlické nádrže 2010. Svazek obcí regionu Písecko a Biologické centrum AVČR, pp. 119-136.

Potužák J, Duras J, Rohlík V, Kubelka A (2011) Látkové bilance vybraných rybníků v povodí VN Orlík. In: Borovec J, Očásková I (eds) Revitalizace orlické nádrže 2011. Svazek obcí regionu Písecko, Povodí Vltavy, státní podnik a Biologické centrum AVČR, pp. 43-61.

Procházková L (1977) Long-term studies on nitrogen in 2 reservoirs related to field. Progress in Water Technology 8: 101-109.

Průša L (2009a) The socio-demographic and economic factors restricting revitalisation of the Orlík reservoir and its surrounding from the further development of tourism in this location. In: Revitalizace orlické nádrže, 6. 10. 2008, Písek. Vysoká škola technická a ekonomická v Českých Budějovicích, pp. 50-56. (in Czech with English summary)

Průša L (2009b) The Strategy of the Revitalisation of the Orlík Reservoir. In: Revitalizace orlické nádrže 2009. Vysoká škola technická a ekonomická v Českých Budějovicích, pp. 5-11. (in Czech with English summary)

Schindler DW (2012) The dilemma of controlling cultural eutrophication of lakes. Proceedings of the Royal Society B-Biological Sciences 279: 4322-4333.

Smith VH, Schindler DW (2009) Eutrophication science: where do we go from here? Trends Ecol Evol 24: 201-207.

Straškraba M, Hrbáček J, Javornický P (1973) Effect of an upstream reservoir on the stratification conditions in Slapy Reservoir. In: Hrbáček J, Straškraba M (eds) Hydrobiological Studies 2. Academia, Prague, pp. 7-82.

Straškrabová V, Hejzlar J, Procházková L, Vyhnálek V (1994) Eutrophication in stratified deep reservoirs. Water Sci Technol 30: 273-279.

WFD (2000) Directive 2000/60/EC of the European Parliament and of the Council establishing a framework for the Community action in the field of water policy. http://ec.europa.eu /environment/water/water-framework/ [accessed on: $26 \mathrm{Au}$ gust 2013].

Withers PJA, Jarvie HP (2008) Delivery and cycling of phosphorus in rivers: A review. Sci Total Environ 400: 379-395. 